\title{
MONITORING OF MICRODISPLACEMENTS IN GOLYAMATA TSEPNATINA CAVE, MADARA PLATEAU, NE BULGARIA
}

\author{
SPREMLJANJE MIKROPREMIKOV V JAMI GOLJAMATA \\ CEPNATINA, VISOKA PLANOTA MADARA, SV BOLGARIJA
}

\author{
Konstantin KOSTOV ${ }^{1}$, Nikolai DOBREV ${ }^{1}$, Josef STEMBERK ${ }^{2}$, \\ Miloš BRIESTENSKÝ ${ }^{2} \&$ Plamen IVANOV ${ }^{1}$
}

\begin{abstract}
UDC 551.24.052:550.34.033(497.217)

Konstantin Kostov, Nikolai Dobrev, Josef Stemberk, Miloš Briestenský \& Plamen Ivanov: Monitoring of microdisplacements in Golyamata Tsepnatina cave, Madara plateau, NE Bulgaria The only early medieval rock bas-relief in Europe Madara Horseman is included in UNESCO World Heritage List. This article presents the results from an in situ monitoring of microdisplacements across fissure forming the Golyamata Tsepnatina Cave located at the edge of Madara Plateau above the Horseman, NE Bulgaria. Additionally, we studied movements along cracks behind the plateau edge, which are related to the dynamics of peripheral plateau parts and shaped the rock slices. Monitoring involves the use of a $3 \mathrm{D}$ extensometer model TM-71 installed in the cave as well as five sets of pin marks installed across the cracks behind the plateau edge. The results obtained since 1990 indicate formation of a new rock slice from the cliff due to the gravitational extension of rock massif. The established horizontal microdisplacements of the rock slice to SSE imply the existence of a possible active fault with left-lateral component of movements at the base of the plateau. We established influences from near and distant earthquakes with epicenters in NE Bulgaria (Provadia), Romania (Vrancea), and Turkey (Izmit). The graphs of established movements mark continuously ongoing process of shear processes along the slice forming cracks.
\end{abstract}

Key words: rock deformations, seismic effects, monitoring, microdisplacements, Madara Plateau, Bulgaria.
Izvleček UDK 551.24.052:550.34.033(497.217)

Konstantin Kostov, Nikolai Dobrev, Josef Stemberk, Miloš Briestenský \& Plamen Ivanov: Spremljanje mikropremikov v jami Goljamata Cepnatina, Visoka planota Madara, SV Bolgarija Edini zgodnjesrednjeveški skalni relief v Evropi, Madarski konjenik, je vključen v Unescovo svetovno dediščino. Ta prispevek obravnava rezultate in situ meritev mikropremikov v razpoki, v kateri je oblikovana jama Goljamata cepnatina, ki se nahaja na robu visoke planote Madara nad Madarskim konjenikom v SV Bolgariji. Dodatno smo proučevali tudi premike razpok za robom visoke planote, ki so odvisni od dinamike robnih delov visoke planote in oblikujejo kamninske bloke. Monitoring vključuje uporabo 3D-ekstenzometra model TM-71, ki je nameščen $v$ jami. Dodatno vključuje tudi pet merilnikov premikov, ki so nameščeni v razpokah za robom visoke planote. Rezultati, ki smo jih pridobili od leta 1990, kažejo nastajanje novih kamninskih blokov iz klifa zaradi gravitacijskega razpiranja kamninske mase. Ugotovljeni vodoravni mikropremiki kamninskih blokov v smeri proti JJV, kažejo, da je možen aktiven prelom $\mathrm{z}$ levo-zmično komponento $\mathrm{v}$ podlagi visoke planote. Ugotovili smo vplive bližnjih in oddaljenih potresov z epicentri v SV Bolgariji (Provadija), Romuniji (Vrancea) in Turčiji (Izmit). Grafi ugotovljenih premikov kažejo dolgotrajne strižne procese vzdolž kamninskih blokov, ki oblikujejo razpoke.

Ključne besede: deformacije kamnin, seizmični učinki, monitoring, mikropremiki, Madara visoka planota, Bolgarija.

\footnotetext{
${ }^{1}$ Geological Institute of Bulgarian Academy of Sciences, Acad. G. Bonchev St., 24, 1113 Sofia, Bulgaria, e-mails: kskostov@ geology.bas.bg, ndd@geology.bas.bg, plivanov62@geology.bas.bg

2 Institute of Rock Structure and Mechanics, Academy of Sciences of the Czech Republic, V Holesovickach 94/41, 182 09, Prague

8, Czech Republic, e-mails: stemberk@irsm.cas.cz, briestensky@irsm.cas.cz
} 


\section{INTRODUCTION}

The caves represent a relatively well protected environment from some of the exogenic geomorphological processes such as deflation, weathering, etc. Because of their almost constant annual micro-climatic conditions, the cavities are very suitable for tectonic studies and monitoring. The main aim of the paper is to present the results of a longterm study with the 3D monitoring of microdisplacements in a fissure along which the study cave was formed. The site is in the NW periphery of the Madara Plateau, about $10 \mathrm{~km}$ E of the town of Shumen, and $80 \mathrm{~km} \mathrm{~W}$ of Varna, NE Bulgaria (Figs. 1 and 2). The historical rock bas-relief called Madara Horseman listed as a protected monument in the World Heritage List of UNESCO is situated here. At this place, near the edge of the plateau and just above the historical bas-relief, a cave is situated, known as Golyamata Tsepnatina ("The Big Crack"), and also as Smelite Ochichki ("The Brave Eyes"). The cave is formed in a fissure between two rock slices, separated from high cliffs on the western periphery of the Madara Plateau.
The rock scarp of the Madara Plateau is subjected to rock slicing producing lamellas, which are removed from the massif through processes of gravitational unloading. These slices are wide from 1 to $3 \mathrm{~m}$. Their height often reaches up to $100 \mathrm{~m}$. Besides, slices not only cause toppling (Varnes 1978) but deformation of landslide type at the foothill of the plateau rockwall, i.e., there is a complex mechanism of deformation in the rocky scarp of the plateau.

To clarify these dynamics, a 3D extensometer TM71 was installed in 1990 (Košták 1991), and later - in 2007-2010 a system of pin marks was installed as well to observe the movements along the cracks behind the plateau edge. The initial purpose of this research was to clarify the rock deformations and their dynamics, and thus to take measures to stabilize the rock scarp. Later, these studies were extended with the periphery of the plateau just above the monument.

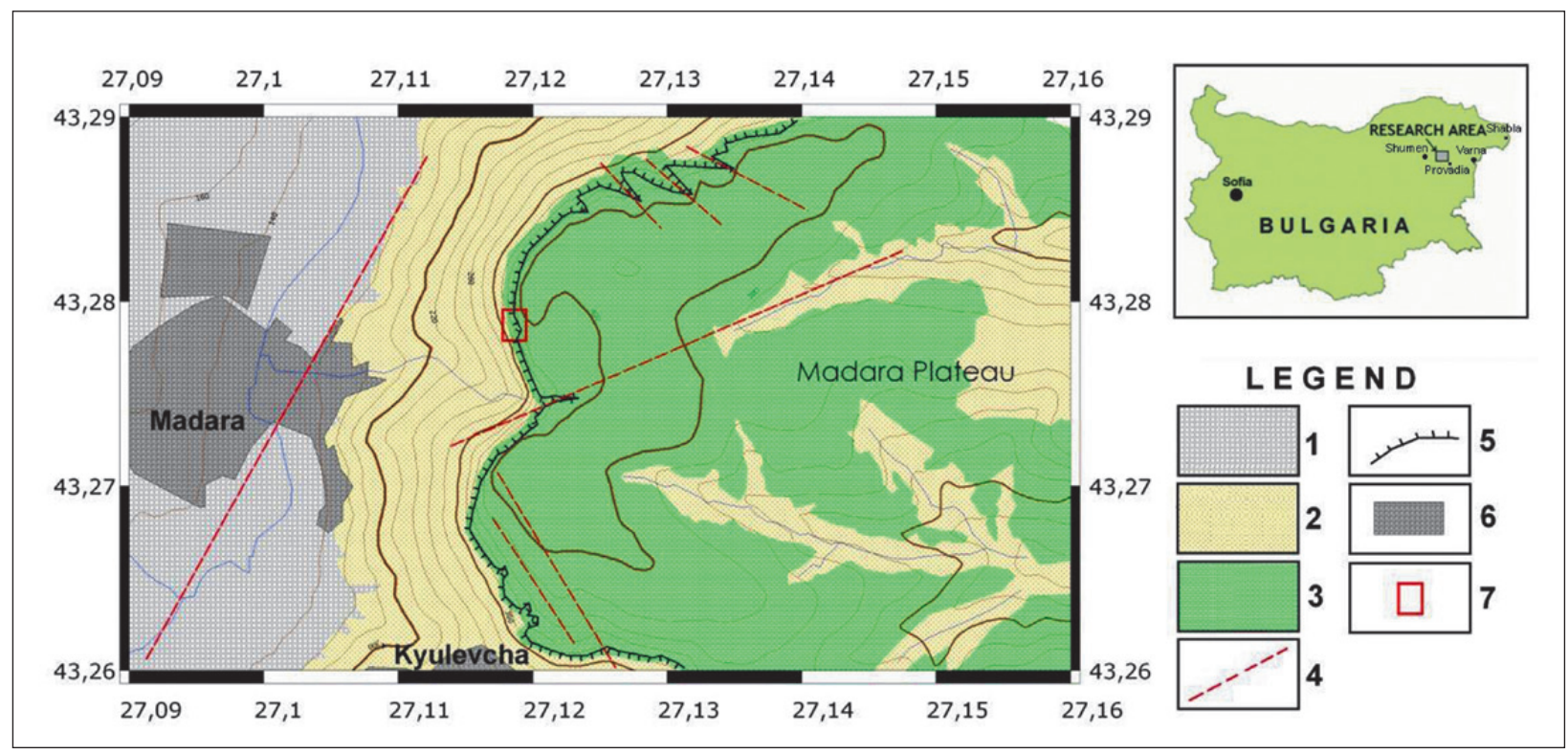

Fig. 1: Situation of study area and geological map of Madara plateau (adopted from Angelova 1995): 1 - Quaternary, alluvial deposits; 2 Quaternary, deluvial deposits; 3 - Cretaceous limy rocks; 4 - possible fault; 5 - plateau edge; 6 - urbanized area; 7 - locality of Golyamata Tsepnatina Cave and Madara Horseman bas-relief.

\section{GEOLOGICAL SETTING}

According to the tectonic division of the territory of Bulgaria, the research area is situated within the western part of the South Moesian platform margin (Dabovski et al. 2002). This unit includes the south dipping subsided part of the Moesian platform in front of the Alpine orogen. The Mesozoic section comprises thick Triassic to Late Cretaceous clastic and dominantly carbonate sediments, locally interfingering with deep marine foredeep 


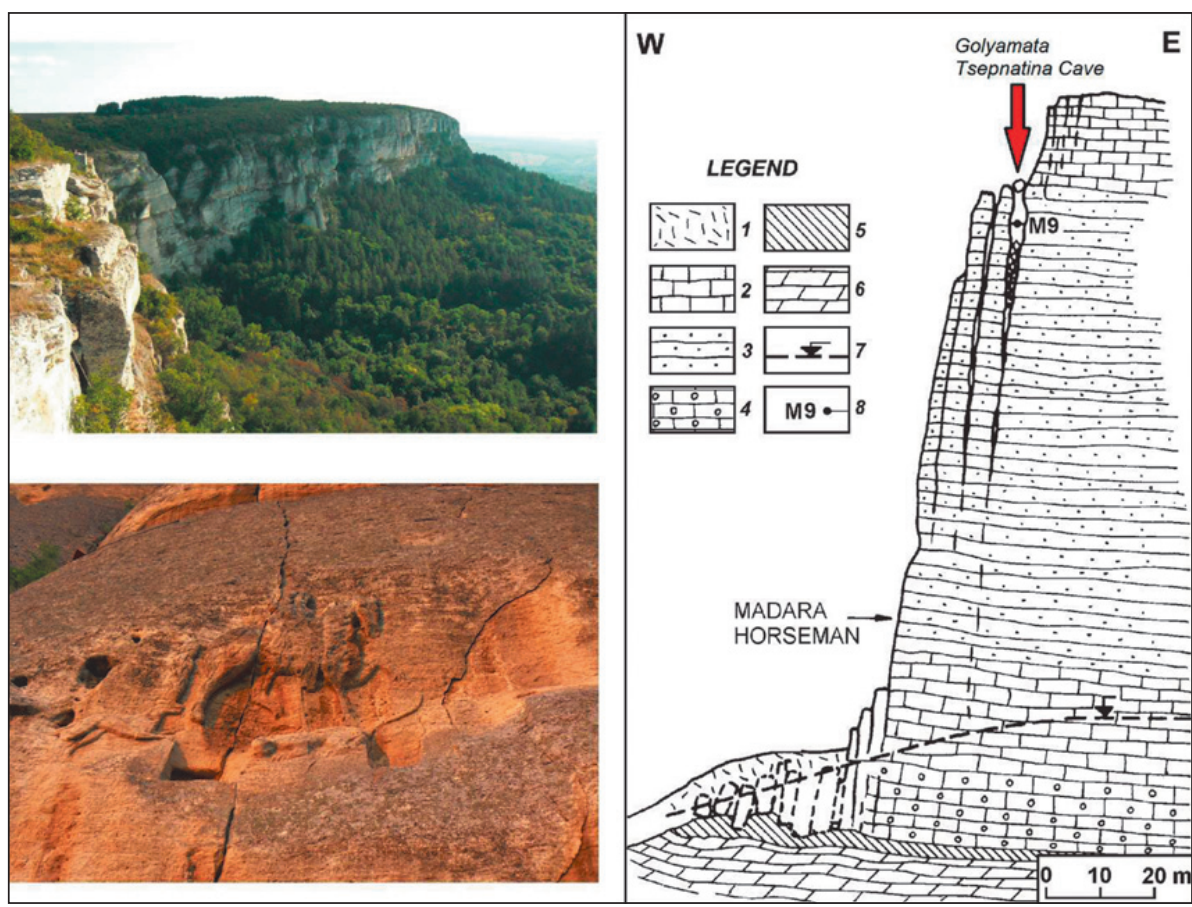

Fig. 2: Left: View on the Madara Plateau above the cave (top) and UNESCO monument Madara Horseman rock bas-relief (bottom). Right: Engineering Geological profile through the Madara plateau (acc. Frangov et al. 1992; Košták et al. 1998): 1 - Deluvium; 2 - Sandy limestones; 3 - Calcareous sandstones; 4 - Conglomeratic limestones; 5 - Clay; 6 - Marls; 7 - Groundwater table; 8 - Monitoring point and location of Golyamata Tsepnatina Cave and fissure F2 (modified after Shanov \& Kostov 2015).

successions (Late Jurassic-Early Cretaceous). The structural pattern is dominated by southern monoclinal dips gently deformed in several synclines. Madara Plateau is in the range of the northern flank of the Provadia Syncline with layers inclined by $5^{\circ}$ to $7^{\circ}$ to SE (Tzankov 1943).

The geology of the region is well studied. At first, this area had been investigated by Toula (1890). Later, the problems of stratigraphy, tectonics, petrography and engineering geology had been described and clarified by Tzankov (1943), Načev and Slavova-Načeva (1961), Nikolov (1969), Karagjuleva (1971) and Yolkichev (1988). Engineering geological problems had been studied by Iliev (1963), Venkov and Kossev (1974), Hadjiev et al. (1977), Frangov et al. (1992), Anguelov et al. (1993), Košták et al. (1998), and others. Geomorphologic aspects had been studied by Vaptzarov and Mishev (1988), and Angelova (1995).

The plateau massif consists of two complexes (Fig. 2): the upper one comprises limy-sandy limestone of Upper Cretaceous - Cenomanian age; the lower one is marly of Lower Cretaceous - Hauterivian age (Toula 1890; Tzankov 1943; Yolkichev 1988). A borehole drilled in 1990, and located into the bas-relief profile in the plateau, penetrated $137.50 \mathrm{~m}$ deep through the Cenomanian rock complex showing several lithologic sub-units (Frangov et al. 1992). The second-lower complex is marly, and consists of greybluish layered marlstones, creeping if heavily loaded. Between the Hauterivian and Cenomanian complexes a layer of yellow plastic silty clay has been discovered. The thickness of this particular layer is approximately $1.5 \mathrm{~m}$.

\section{SITE DESCRIPTION}

\section{SLOPE GEOMORPHOLOGY AND DEFORMATION MODEL}

The western part of Madara Plateau is elevated up to 250 meters above the local base level of Madara River. The rock cliff has a maximum height of $120 \mathrm{~m}$ in the central part of the plateau. This height decreases to the north up to $30-40 \mathrm{~m}$, and 2-3 km south from the village Kyulevcha (Fig. 1) almost disappears. The surface of the plateau is almost flat to slightly hilly. There is a slight slope inclination to the east.

The peripheral part of the plateau is characterized by slice-like structure. Up to 6 rock slices can be recognized at plateau rockwall. They cut all Upper Cretaceous sequence of limestones and calcareous sandstones from the plateau edge to its base in the Hauterivian marlstones. Behind the plateau edge, another 1-2 slices are in pro- 


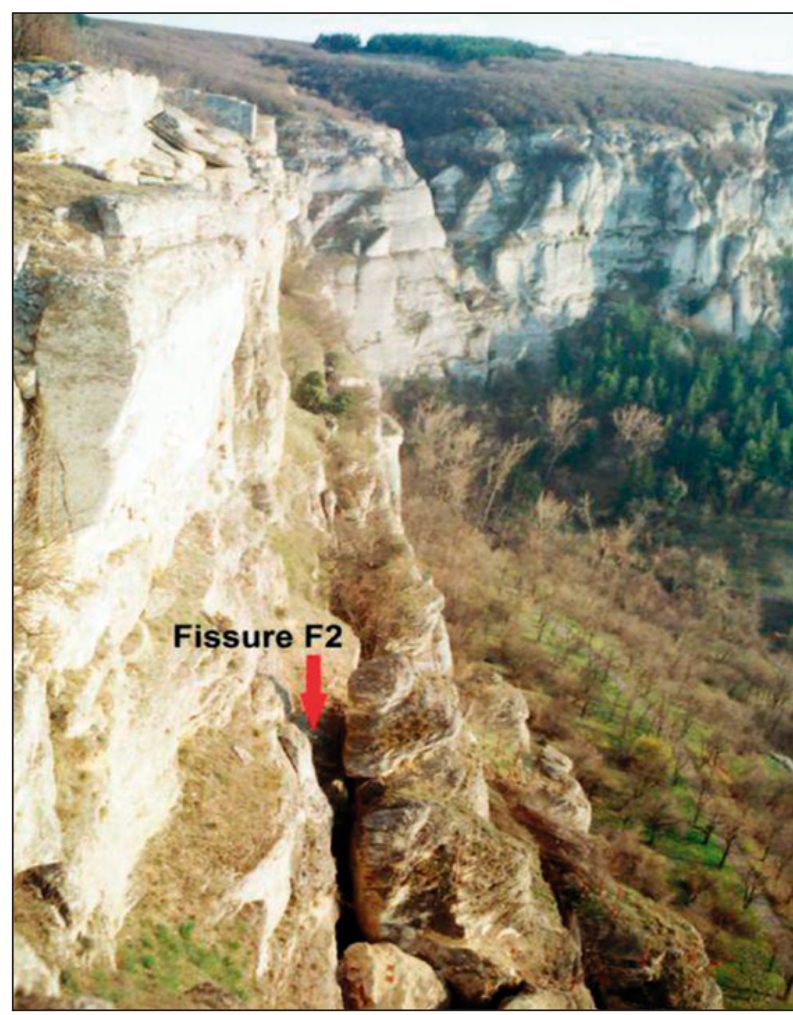

Fig. 3: A view of fissure F2 taken in March 1996 (Photo: N. Dobrev).

cess of formation and separation from the plateau, but they are not destabilized and sank yet into the soft marly substrate. In a seemingly stable (flat) part of the plateau there are signs of emerging new 1 or 2 slices. They are expressed as fissures (subparallel to the edge of the plateau) or as small cleft karren.

The rock wall is almost vertical, built by a limestonecalcareous sandstone complex. The explanation of sliced structure of the plateau scarp is connected with the high deformability of the marly bedrock due to water percolation, as well as with the gravitational extension of the massif. Downwards the slope marlstones are covered by deluvial deposits sloping from $10^{\circ}$ to $20^{\circ}$. Angelova (1995) suggested a fault location at the base of the plateau which orientation is approximately NNE-SSW. It is possible to take place movements along the fault affecting the dynamic processes at the plateau's periphery.

Fissures that develop during gravitational extension in this slope and its splitting were given with the sign " $\mathrm{X}$ " by different investigators (Venkov \& Kossev 1974; Hadjiev et al. 1977; Frangov et al. 1992; Košták et al. 1998). The two uppermost and most extended fissures at present are described as F1 and F2 (previously described as X1 and X2 by Venkov and Kossev (1974), and others) separating two slices from the plateau (Fig. 3). For the other subparallel cracks located in the direction of the plateau, we give names F3, F4 and F5.
The first three slices (F1-F3) can now be found as very low steps in the lowest section of the wall, being relics of old frontal blocks disintegrated in their towering heads. Formation of two or three new slices about $3 \mathrm{~m}$ wide can be detected behind the furthermost edge of the plateau by traces of cracks.

\section{GOLYAMATA TSEPNATINA CAVE: LOCATION AND MORPHOLOGY}

Golyamata Tsepnatina Cave is formed along fissure F2 (Fig. 2), oriented in $150^{\circ}$ to $170^{\circ}$ direction (SSE) dipping $80^{\circ}$ to W. It is $1.2 \mathrm{~m}$ wide in its uppermost part, and $3 \mathrm{~m}$ wide in the lower part, with recent vertical span of $6 \mathrm{~m}$. It was inspected to the depth of $12 \mathrm{~m}$. Further research was hampered by filling the cave with broken material. Total length of the cave is $70 \mathrm{~m}$.

The cave is located $80 \mathrm{~m}$ above the Madara Horseman rock bas-relief. The cave entrance is accessible by $25 \mathrm{~m}$ descent from the edge of the plateau using singlerope technique (SRT) (Fig. 4). After artificial entrance and another 7-m rope descend, the main gallery of the cave can be reached. It is developed in the Cenomanian sandy limestones and calcareous sandstones, the cave is a good example for the structural control in karst. Sediments are presented by weathering detritus, breakdowns and organogenic material (guano).

The cave was investigated and surveyed in 1971 by cavers from "Galata" Caving Club - Varna. Second detailed survey was made in 1985 by the Shumen cavers A. Spasov and M. Mirchev ("Madarski Konnik" Caving Club). Description of the cave is given in Mircheva et al. (2004) and Shanov \& Kostov (2015). The cave has no special protection status but is situated within the bound-

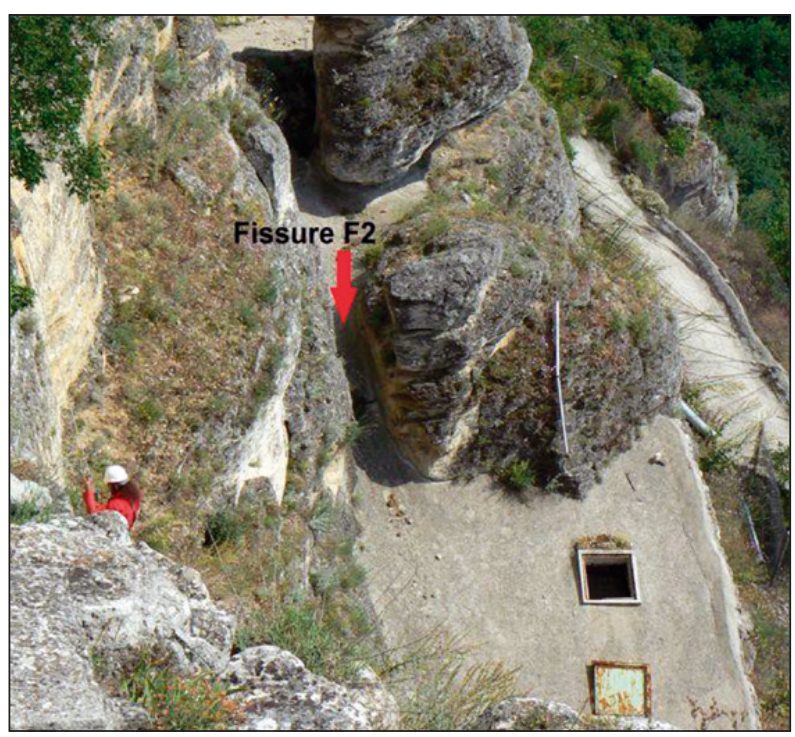

Fig. 4: The entrance of Golyamata Tsepnatina Cave (fissure F2) with the concrete roof (Photo: N. Dobrev). 


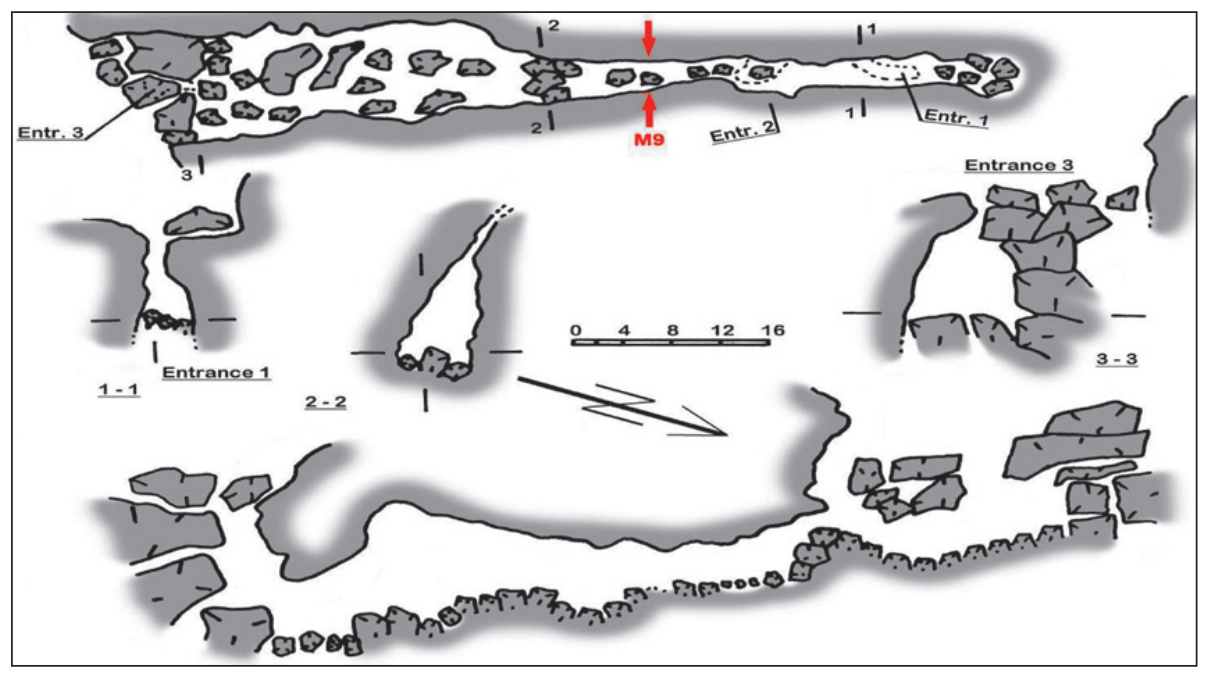

Fig. 5: Map, cross sections and longitudinal profile of Golyamata Tsepnatina Cave (after Mircheva et al. (2004), Shanov \& Kostov (2015)). The scale is in meters. Location of installed monitoring gauge is shown in red arrows.

aries of the National Historic-Archaeological Reserve "Madara" (Fig. 5).

In the fall of 1999, the fissure F2 was covered by a reinforced concrete roof, built for protection from penetration of rainfall waters, since it was assumed that they influence the slope movements (Fig. 4). The purpose is to minimize impact deformation of the outermost rocky slices, where the Madara Horseman monument is carved.

\section{SEISMICITY}

According to the seismotectonic prognostication of NE Bulgaria, the Madara Plateau and its wider region are characterized with high potential seismicity where earthquakes with magnitudes more than 5 could be generated (Kostadinov et al. 1992). At the same time, the region is sensitive to seismic effects coming from outside the country. This may be exemplified by Vrancea earthquakes (Romania) May 30 and 31, 1990, M=6.7 and 6.1, respectively (Radu et al. 1990). The closest epicentral areas are near to the town of Provadia (25 km SE from Madara), then in the regions Shabla-Kaliakra (100-120 km NE from Madara), Gorna Oryahovitsa-Strazhitsa (75-100 km W from Madara) and Izmit Earthquake in Turkey, August 17, 1999 (about 200 $\mathrm{km}$ SSE from Madara).
The last strong earthquakes after 1900, that came from outside of the Madara plateau area, are those of Shabla 1901, $M=7.2$, Gorna Oryahovitsa 1913, $M=7.0$, Vrancea 1940, M=7.3, Shabla 1956, M=5.5, Vrancea 1977, M=7.2, Strazhitsa 1986, M=5.7 (Shebalin et al. 1974; Solakov \& Simeonova 1993).

Till present, we have information (Matova et al. 2001; Dobrev 2010) on impact of distant earthquakes on the stability of the Madara plateau rock wall. These are the falls of rock blocks with different volumes during the earthquakes of Vrancea (May 1990) and Izmit (August 1999).

Within the last ten years, the Madara Pleateu was shaken by few earthquakes occurred in Vrancea (Romania), Provadia and Black Sea (Bulgarian zone). The strongest of them occurred in Vrancea on October 6, $2013(\mathrm{M}=5.0)$ and November 22, $2014(\mathrm{M}=5.6)$ located 250-290 km north from Madara. The epicenter of Provadia Earthquake on October 7, $2010(\mathrm{M}=4.5)$ is located 35 $\mathrm{km}$ east from Madara. After the Kamen Bryag Earthquake (August 5, 2009, M=5.0, $100 \mathrm{~km}$ ENE from Madara) rockfalls are observed in caves along Northern Bulgarian Black Sea coast (Kostov 2014; Kostov \& Nikolov 2013). The earthquake in the Black Sea offshore zone on December 3, $2012(\mathrm{M}=5.0)$ is located $125 \mathrm{~km} \mathrm{NE}$ from Madara.

\section{METHODS AND MONITORING TOOLS}

The extensometers (crack gauges) TM-71 permit detection of micromovements, with application of highly sensitive equipment, durable to external climatic influences and providing opportunities for long-term monitoring. It was developed in the Czech Republic by Dr. Blahoslav Košták (Košták 1991). During the last decades the us- age of 3D extensometers TM-71 has been applied with success in several caves in Czech Republic, Slovakia, Belgium, Slovenia, Bulgaria and Poland (Cacon et al. 1993; Šebela et al. 2005, 2009, 2010; Briestenský \& Stemberk 2007; Briestenský et al. 2015; Stemberk et al. 2008; Mąkolski et al. 2008; Gosar et al. 2009, 2011, and others). 


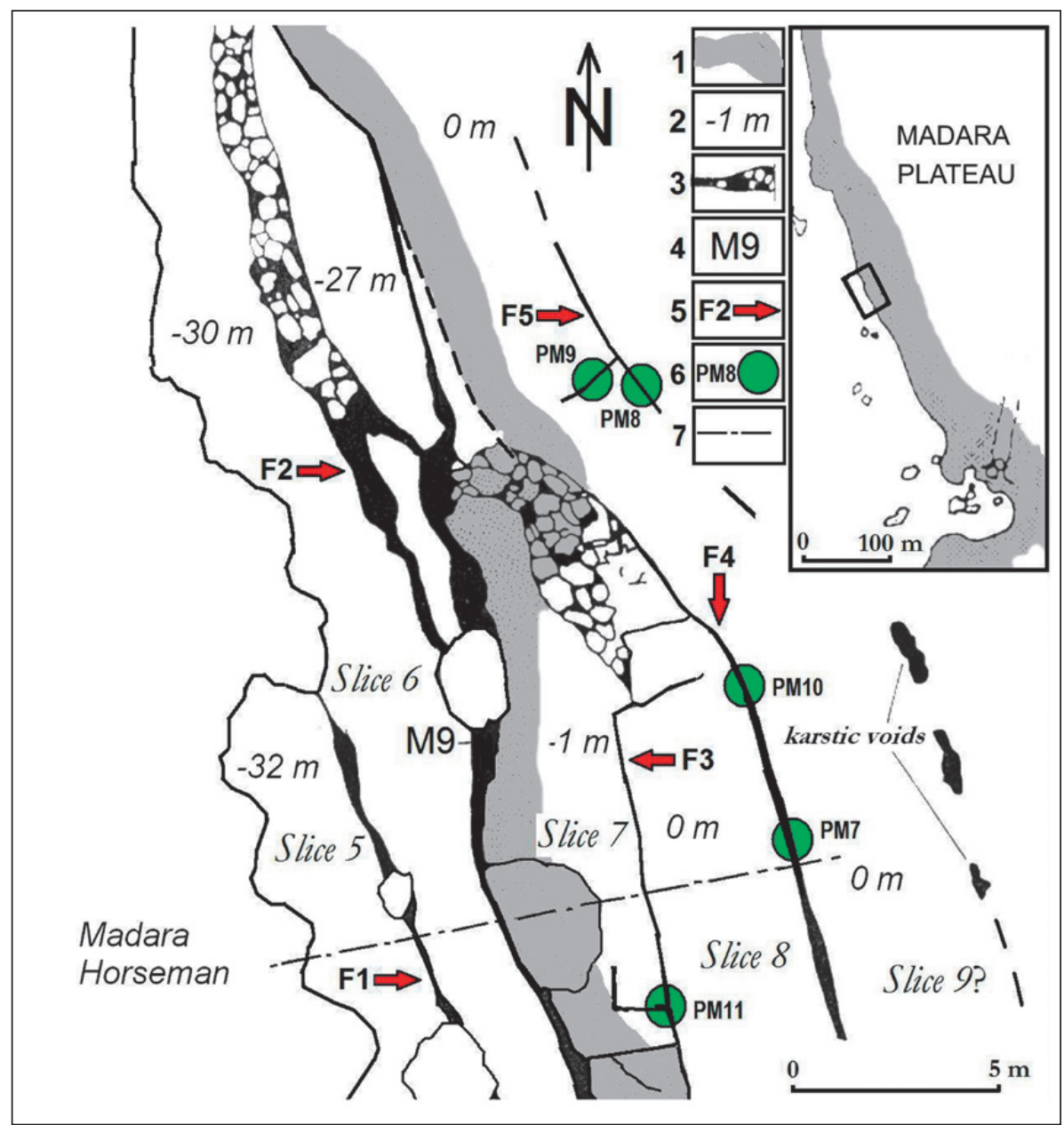

Fig. 6: Situation of pin marks in the area behind the plateau edge (modified after Košták et al. (1998)). 1 main plateau edge zone; 2 - relative subsidence from the plateau level; 3 - fissure; 4 - location of extensometer; 5 - fissure No.; 6 - pin marks No.; 7 - profile shown in Fig. 2.

Golyamata Tsepnatina was the first cave with regular extensometric monitoring in Bulgaria.

The extensometer works on the principle of mechanical interference - Moiré effect, which records displacement as a fringe pattern on superposed optical grids, mechanically connected with the opposite walls or crack faces. Due to this principle, which completely avoids any electrical transmissional means (electrical components), the gauge displays an extremely large long-term stability, and infallible performance under hard outdoor conditions. The results represent displacements in Cartesian coordinates $(\mathrm{X}, \mathrm{Y}, \mathrm{Z})$, where " $\mathrm{X}$ " means horizontal crack dilation, " $\mathrm{Y}$ " means strike-slip along fault or fissure and " $Z$ " means vertical displacements (this principle refers to horizontal installation as well as X coordinate orthogonal to fault striking). Then results can be converted to displacements on structural planes in $\mathrm{mm}$, and time trends derived as rates in $\mathrm{mm}$ per year under hard field conditions in a prolonged operation. The accuracy of instrument is $0.05-0.0125 \mathrm{~mm}$ in all three space co-ordinates and $3.2 \times 10^{-4}$ radians in angular deviations. Temperature effects in the system including arms are eliminated numerically, while such ef- fects upon the rock are not eliminated in the data and are observable in climatic cyclic variations. The reading appears in a form of interference patterns photographically registered and interpreted in laboratory.

All details about the principle, the gauges, and the evaluation formulas are published elsewhere (Košták 1991; Klimeš et al. 2012; Rowberry et al. 2016). The experience shows that the gauges in performance of several years can provide reliable data about deformation trend as low as $0.1 \mathrm{~mm}$ per year or even more.

Additional monitoring points - simple pin marks were installed in 2008 with aim to clarify the dynamics of crack movements behind the edge of the plateau. Thus, we have received indicative values of expansion/ compression (axis X) and/or slipping along the observed crack (axis Y). These new points (pin marks=PM) are numbered from 7 to 11 (Fig. 6). Measurements were carried out with an electronic calliper Starrett 721A-6/150 (accuracy $0.01 \mathrm{~mm}$ ) and Mitutoyo $750 \mathrm{~mm}$ (accuracy $0.01 \mathrm{~mm}$ ). The pin marks are installed across fissures separating slices 7 and 8 (pin marks 11), 8 and 9 (pin marks 7 and 10) and 9-10 (pin marks 8 and 9). 


\section{RESULTS}

\section{MONITORING IN THE CAVE}

As seen on the profile (Fig. 2), the cave is formed along the fissure parallel to the plateau edge and separating two slices apart. The device connects both rock walls of the opposite slices by iron arms with a total length of $3.2 \mathrm{~m}$ (Fig. 7). The observations at this site were made in different time intervals. From April 1990 until the end of 1994 observations were carried out twice a month. After this period, observation frequency has been changed to 4-5 times per year. Monitoring was interrupted two times: from early 1996 until the summer of 1997 and from early 2003 to September 2007.

During the period of monitoring, the plateau underwent several local and distant earthquakes. As it is evident (see Fig. 8) below, significant changes in displacements are noticeable just during two of them - both earthquakes are strong and are outside Bulgaria. Information obtained up to the present indicates that there are several stages of microdisplacements, which are shown in Tab. 1.

The first strong displacement jolt occurred less than two months after the installation of the monitoring apparatus. The change was related with earthquakes in Vrancea (Romania) occurred on May 30 and 31, 1990. Due sparse monitoring interval (twice a month), we were not able to distinguish preseismic, coseismic or postseismic deformations. The sense is relative, but it

indicates SSE movement of the slice No. 6. There is a visible large movement of vertical component $Z$ (Fig. 8). Because the graphic expression of displacements shows a clear peak-to- peak amplitude (due to seasonal temperature variations in rock massif) we applied approach used

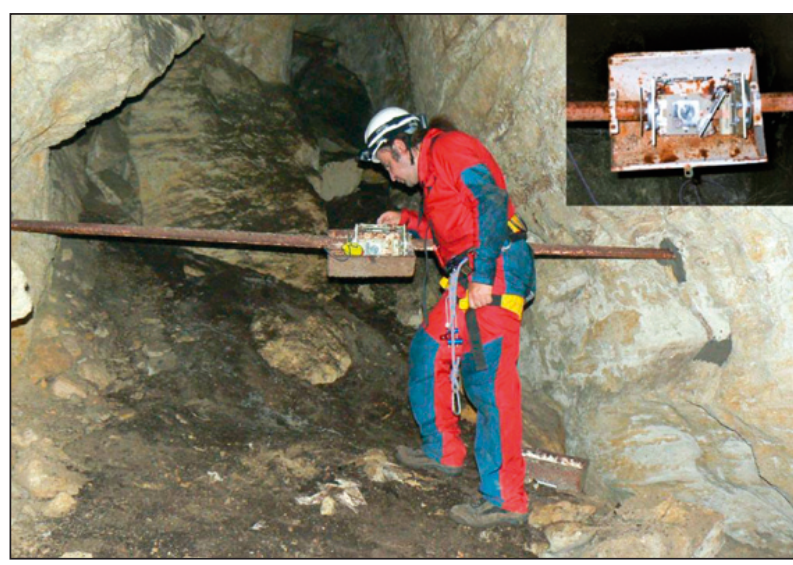

Fig. 7: Regular measurements at Golyamata Tsepnatina Cave, monitoring site M9 with monitoring gauge damaged after August 1999 Izmit Earthquake (upper right corner) (modified after Shanov \& Kostov (2015)).

by Dobrev and Avramova-Tacheva (1997) to separate the sinusoidal displacement component and to obtain 1.4 $\mathrm{mm}$ sinking of the external slice No. 6 during the Vrancea earthquakes in May 1990.

From May 1990 until the end of 1993, the displacements reflect a sinusoidal character. The most pronounced trend is again subsidence of the slice with 1.057 mm per year.

Further, during the next 3 years (1993-1995) the sinusoidal character of curve of displacements is not clearly expressed. The movements already have highly variable (unspecified) character, with typical sharp movements and without any apparent trend. At the end of 1994 sharp jumps are detected: opening the crack by $1.1 \mathrm{~mm}$ at axis

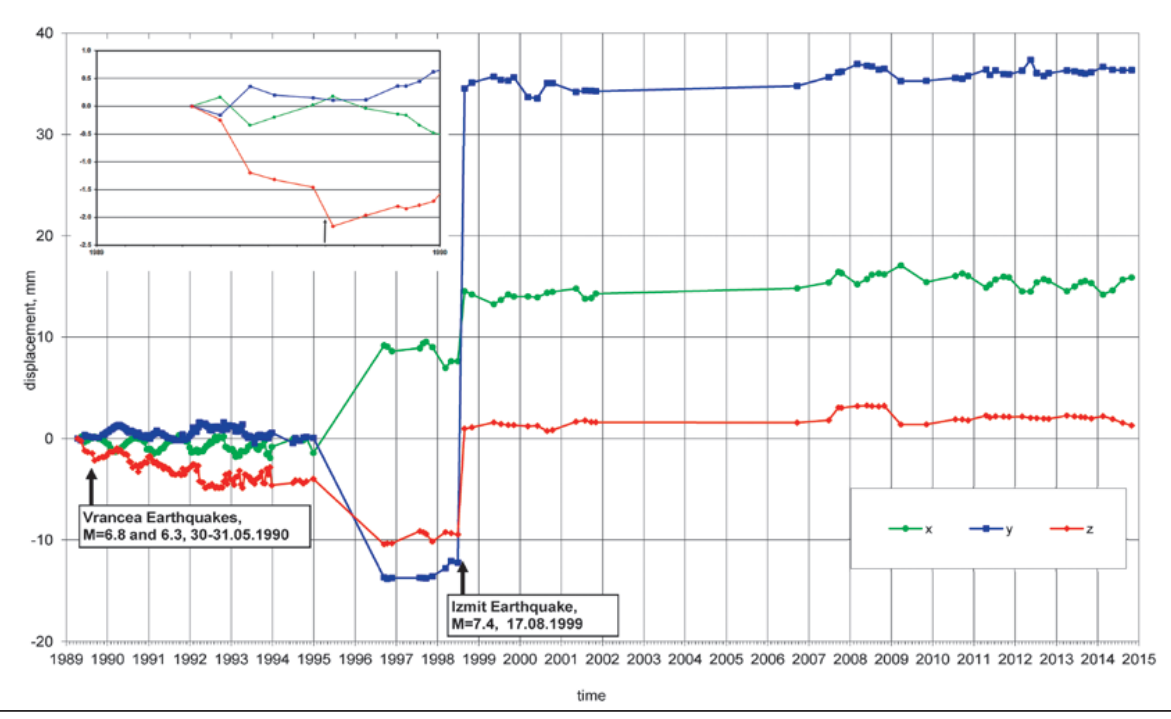

Fig. 8: Result of extensometric monitoring in the Golyamata Tsepnatina Cave. The graph shows effect of distant earthquakes on fault displacements registered across SE striking fissure; $+X-$ shortening of the fissure; $+Y-$ sinistral strike-slip of rock slice No. 6; $+Z$ - uprise of rock slice No. 6. In the small figure: detail of measurements in 1990 with seismic effect. 
$\mathrm{X}$ and $1.8 \mathrm{~mm}$ subsidence of the slice No. 6 . There is no explanation for this sharp movement so far.

After almost two-year interruption of monitoring (from December 1995 to September 1997), when the measurements were again restored, significant displacements were established: compression of $10.6 \mathrm{~mm}$ (axis $\mathrm{X}$ ); slip of slice No. 6 to SSE with $13.6 \mathrm{~mm}$ (axis Y) and uprising of slice no. 5 with $6.5 \mathrm{~mm}$ (axis Z).

We estimated that the past period is not characterized by local seismic activity that could impact the microdisplacements along the observed crack in the cave, for example occurred in the Provadia region. However, observations from other extensometric points in Europe also show similar trends (reactions) that are associated with stronger seismic events with high values of released energy. Such seismic events are: significant earthquakes in Pakistan (February 27, 1997, M=7.1) and Iran (May 10, 1997, M=7.3) at the beginning of 1997 (Kontny et al. 2005). Impulse impacts from these earthquakes are detected by observation points in other parts of Bulgaria and Europe as Kresna Gorge, Kaskad and Izmit area (Košták et al. 2007, and others).

For the short period of two years after the restoration of observations (September 1997 - August

1999) movements are characterized by extension of the fissure (axis X), slipping on SSE (axis Y) and relative rising of the slice (axis Z) with $0.835 \mathrm{~mm} / \mathrm{yr}$. The latter is due to the ongoing process of subsidence of the upper slice no. 6 . This process continues to the present.

The Izmit earthquake on August 17, 1999 shook vigorously the Madara Plateau although it was at a distance of about $370 \mathrm{~km}$ from the epicentral area. This

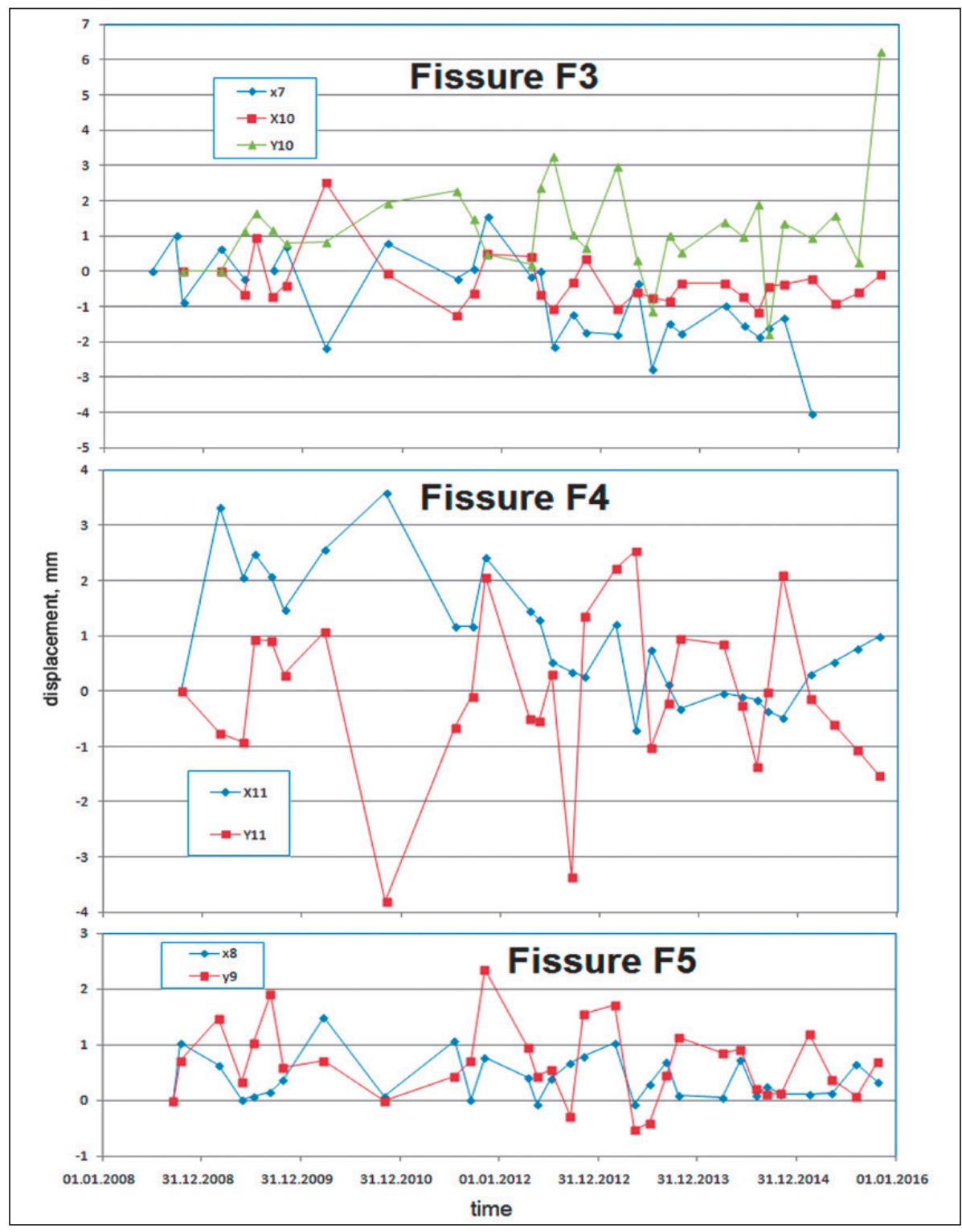

Fig. 9: Graphs of movements established at pin marks on fissures F3, F4 and F5 behind the plateau edge. $+X$ means extension of the fissure in $\mathrm{mm}$ (X7, X8, X10 and $X$ 11 means axis $X$ from pin marks No.7, 8, 10 and 11): $+Y$ - horizontal slip of pin marks 10 (Y 10) means the slice No. 7 to $315^{\circ} \mathrm{NNW}$, horizontal slip of pin marks No. 11 means the slice No. 8 to $153^{\circ}$ SSE. 
Tab. 1: Trends of microdisplacements established at point M9 for the period 1999-2015.

\begin{tabular}{|c|c|c|c|}
\hline axis & $X$ & Y & Z \\
\hline period & \multicolumn{3}{|c|}{ May 30-31 1990 Vrancea earthquakes } \\
\hline Yearly velocity, mm/year & $\sim 0.50$ & $\sim 0.50$ & -1.40 \\
\hline Meaning of movement & compression of the fissure & horizontal slip to SSE & subsiding of slice No. 6 \\
\hline Number of measurements $n$ & 2 & 2 & 2 \\
\hline period & \multicolumn{3}{|c|}{ April 1990 - December 1993} \\
\hline Yearly velocity, mm/year & 0.154 & -0.038 & -1.057 \\
\hline Meaning of movement & compression of the fissure & horizontal slip to NNW & subsiding of slice No. 6 \\
\hline Number of measurements $n$ & 79 & 79 & 79 \\
\hline period & \multicolumn{3}{|c|}{ January 1994 - December 1995} \\
\hline Yearly velocity, mm/year & 0.553 & -0.049 & -0.102 \\
\hline Meaning of movement & compression of the fissure & horizontal slip to NNW & subsiding of slice No. 6 \\
\hline Number of measurements $n$ & 31 & 31 & 31 \\
\hline period & \multicolumn{3}{|c|}{ December 1995 - September 1997} \\
\hline Displacement, mm & 10.6 & $\sim-13.6$ & $\sim-6.5$ \\
\hline Meaning of movement & shortening of the fissure & horizontal slip to NNW & subsiding of slice No. 6 \\
\hline Number of measurements $n$ & - & - & - \\
\hline period & \multicolumn{3}{|c|}{ September 1997 - August 1999} \\
\hline Yearly velocity, mm/year & -0.854 & 0.615 & 0.835 \\
\hline Meaning of movement & extension of the fissure & horizontal slip to SSE & $\begin{array}{r}\text { vertical movement (uplift) of } \\
\text { the rock slice No. } 6 \\
\end{array}$ \\
\hline Number of measurements $n$ & 10 & 10 & 10 \\
\hline period & \multicolumn{3}{|c|}{ August 171999 Izmit Earthquake } \\
\hline Co-seismic displacement, $\mathrm{mm}$ & 6.91 & 46.78 & 10.43 \\
\hline Meaning of movement & compression of the fissure & horizontal slip to SSE & $\begin{array}{r}\text { vertical movement (uplift) of } \\
\text { the rock slice No. } 6\end{array}$ \\
\hline Number of measurements $n$ & 2 & 2 & 2 \\
\hline period & \multicolumn{3}{|c|}{ May 2000 - March 2009} \\
\hline Yearly velocity, mm/year & 0.228 & 0.154 & 0.171 \\
\hline Meaning of movement & compression of the fissure & horizontal slip to SSE & uplift of the rock slice No. 6 \\
\hline Number of measurements $n$ & 17 & 17 & 17 \\
\hline period & \multicolumn{3}{|c|}{ May 2009 - February 2015} \\
\hline Yearly velocity, mm/year & -0.297 & 0.018 & 0.120 \\
\hline Meaning of movement & extension of the fissure & horizontal slip to SSE & uplift of the rock slice No. 6 \\
\hline Number of measurements $n$ & 25 & 25 & 25 \\
\hline
\end{tabular}

earthquake was felt in many parts of Bulgaria, including the nearest towns of Shumen and Varna. It was felt by the residents as a continuous mild shaking. During the earthquake, the local residents have noticed a totter of slices and manifestation of rockfalls. An inspection of the cave was made on August 28, 1999 - 11 days after the earthquake. We found that the apparatus was seriously damaged - parts of the measuring elements were broken (Fig. 7). Although this was a reconstruction of the deflection, which showed a narrowing of the cave with about $6.91 \mathrm{~mm}$ (axis X), sliding the slice of SSE with approx.
$46.78 \mathrm{~mm}$ (axis $\mathrm{Y}$ ) and subsidence of the upper slice no. 6 of $10.43 \mathrm{~mm}$ (see Tab. 1).

The period after the Izmit earthquake 1999 can be described as relatively calmer than before. The velocities show lower values. Two stages can be distinguished - one from 2000 to 2009, and the other from 2010 to 2015. During whole period, the process of separating of the new slice (No. 7) behind the edge of the plateau is dominating, which is subsiding faster than the below lying slice No. 6 . Across axis X, the period: 1999-2009 shows compression and 2010-2015 - extension. 
From beginning of 2008 to beginning of 2010, an anomaly in the motion of axes $\mathrm{Y}$ and $\mathrm{Z}$ is established, which is expressed in jump when moving to the beginning of the period and compensation at the end. A similar case was registered by extensometer E2 in Budapest (Hungary) displayed the same compressional regime until the end of 2009 and followed by different regimeextension (Eper-Pápai et al. 2014).

Analysis of movements in the period 2010-2015 shows that it can be divided into two stages: the first from May 2000 to March 2010 and the second from March 2010 to 2015. There were published overplate tectonic pulse affected whole European plate at the end 2014/ beginning 2015. It was registered in Greece, Central Europe and up to the north border in Spitsbergen (Briestenský et al. 2015). Moreover, there is an anomaly in the movement at $\mathrm{Y}$ in the first half of 2013. It is expressed in the accelerated sliding of the slice to SSE with a consequent return of the same size. It had oscillatory character. This pulse was observed in Saeva Dupka and Bacho Kiro in Bulgaria at the end of 2012 and beginning 2013, too. Both caves displayed the pulse simultaneously with monitoring points in Slovakia, Slovenia, Czech Republic or Kyrgyzstan (Briestenský et al. 2015).

Calculated mean velocities of displacements registered at monitoring point M9 are shown in Tab. 1.

\section{MONITORING OUTSIDE THE CAVE}

The installation of the pin marks has been carried out in 2007-2008 and despite the short period of observation the following results are obtained:

Although the brief period of measurements, the monitoring with the pin marks indicates movements in cracks behind the edge of the plateau. Sudden jumps in movement show seasonal peak-to-peak amplitude of the contraction and expansion, most clearly distinct in pin marks 9 and 10.

At pin marks No.7 we found a sharp jump of $2.7 \mathrm{~mm}$ which could be connected as an effect from November 22, 2014 Vrancea earthquake $(M=5.6)$. Possible effects of earthquakes are identified by the $\mathrm{Y}$ axis in point 11 . These may be from the earthquakes in Provadia (October 7, 2010, M=4.5) and the Black Sea Shelf of Bulgaria (December 3, 2012, M=5). These two outbreaks are likely to cause slip of the lower slice to SSE with $4.9 \mathrm{~mm}$ and 2.6 $\mathrm{mm}$, respectively.

At all pin marks, we observe periods that could be characterized with an initial slight acceleration of movements, followed by a sharp decline with amplification of these movements again (Fig. 9). Periods of each cycle lasts from 3 to 8 months. This type of movement is established on both spatial axes, $\mathrm{X}$ and $\mathrm{Y}$. In most cases they do not depend on each other.

\section{CONCLUSION}

The results obtained up to present show that the cave can be characterized as a dynamic structure where various factors take part: tectonic movements, gravitational extension of massif, slope processes (rock toppling, lateral spreading, etc.), and also the effects of earthquakes. Groundwater level is deep-seated, but in the formation of caves, precipitation water's draining along the fracture systems have a major influence. Correlation between extensometric results and water level was discussed e.g., by Camelbeeck et al. (2012) and Stemberk et al. (2017) but in this research area, similar observations have not been made. Cave entity, which is formed near the edge of the plateau is in the unstable and dynamic state. The two walls of the cave are formed by cleavage of the plateau rock slices. These are two vertical rock slices, which are in constant motion relative to each other, the overall trend is to sink down the slope and simultaneously to creep slowly to SSE. There is evidence that cave formation exists in other sub-parallel cracks. Basis for this also provide karst established during the first field studies of the rock mass in 1990 (Košták et al. 1998, see. Fig. 6). During these studies, karst voids (karren forms) have been identified behind rock slice No. 9 .

The recent tectonic movements are another factor that should be taken into account. As we mentioned above, Angelova (1995) suggested the presence of a fault at the foot of Madara Plateau through analysis on geomorphological and geological data. The fact that there is a creep of slices to SSE shows that the occurrence of such movements has left-lateral components. Similar cases are described for the cliff along Crimean Peninsula by Klimchouk et al. (2013) and for cliff at the Mužský Hill Plateau margin (Stemberk et al. 2017).

All movements established to date, show evidence of micromovements on the cracks shaping the cave. The same movements are established in cracks behind the plateau edge. The movements in the cave are related mainly with the separation of rock slices of the plateau, i.e., by extensional regime at the end of rock massif. These movements are intermittent, with variable character depending on the irregular activation of the release of a new slice formed behind the edge, as well as the purely gravitational move- 
ment of rock slice off the plateau. These movements are variable signs as triggering the process of separating the slice that occurs during earthquakes. Obviously, the new slice is in a relatively unstable position than the older ones.

The separated rock slices carry out this movement with mutually offsetting motions, always following the general trend referred to above. This trend of movement is generally constant, except during the periods of external influences of stronger regional earthquakes, such as those in Vrancea or Turkey. Relative subsidence of one of the slices is realized, with tilts, large residual deformations and collapse of rock material (rockfalls and rocktopples). There are also large movements, which cannot be explained as a result of seismic impact.

The movements registered at pin marks are characterized by few months periods in graphs that illustrate the process of shearing or destruction (shear or stressstrain curves) - it is a gradual acceleration of strains that resemble the type of shear or stress-strain graphics (i.e., overcome the peak shear or compressive strength of rock). Therefore, we can assume that the movements at the upper parts of the plateau are mostly determined by the overcoming of shear stress between two adjacent rock slices at the periphery of the plateau.

The results obtained by extensometric monitoring show ascertainment of earthquakes' effects on microdisplacements along the cracks at the upper parts of the plateau. There are large variations, mainly related to the compression and extension of the cracks, but also with slight acceleration movements on the other axes (subsidence and slip to the south). Local earthquakes occur mainly at two source zones, namely Provadia $(20 \mathrm{~km} \mathrm{E})$ and Shabla-Kaliakra (100 km ENE). Only part of these events influences the movements, mainly from Provadia source zone (Košták et al. 1998, Dobrev 2010). The largest effects were established after the earthquakes in Vrancea, Romania, from May 30-31, 1990 (M=6.8 and 6.3), and the second one - with a higher value after the Izmit Earthquake, Turkey. The monitoring point M9 recorded sharp displacements as the following: $\Delta \mathrm{X}=+6.91 \mathrm{~mm}$ compression of the fissure; $\Delta \mathrm{Y}=+46.78 \mathrm{~mm}$ horizontal slip to SSE; $\Delta \mathrm{Z}=+10.43 \mathrm{~mm}$ vertical movement (uprising) of the rock slice No.7 (i.e., sharp subsiding of a newformed slice behind the plateau edge).

\section{ACKNOWLEDGEMENTS}

The research activities were possible by the financial support of Ministry of Culture of Bulgaria and passed through the following: bilateral project "Monitoring and prognosis of geodynamic hazard processes", 2013-2016, joint research project between Geological Institute of Bulgarian Academy of Sciences and IRSM, Academy of Sciences of Czech Republic, and by the long-term conceptual development research organization RVO: 67985891 and CzechGeo (LM2015079). We would also like to thank Mrs Nataliya Kostova for helping with the shaping of this article and to the anonymous referee for the useful comments on the manuscript.

\section{REFERENCES}

Angelova, D., 1995: Neotectonics and geodynamics of the Madara Plateau.- Problems of Geography, Bulg. Acad. of Sci., 2, 75-85 (in Bulgarian with English abstract).

Anguelov, K.A., Konstantinov, B.K., Lakov, A.V. \& S.B. Stoinev, 1993: Stability of the bas-relief of the Madara Horseman (NE Bulgaria).- In: Anagnostopoulos, A. et al. (eds.) Geotechnical Engineering of Hard Soils - Soft Rocks: Proceedings of an International Symposium under the auspices of the ISSMFE, $20^{\text {th }}-23^{\text {rd }}$ September 1993, Athens, Greece. Balkema, 1045-1049, Rotterdam.

Briestenský, M., Stemberk, J. \& L. Petro, 2007: Displacements registered around the 13 March 2006 Vrbové earthquake $\mathrm{M}=3.2$ (Western Carpathians). Geologica Carpathica, 58, 5, 487-493.

Briestenský, M. \& J. Stemberk, 2007: Recent displacements registered in selected caves of Dobra Voda karst area in Slovakia.- Acta Geodyn. Geomater., 4, 1, 31-38.

Briestenský, M., Rowberry, M.D., Stemberk, J., Stefanov, P., Vozár, J., Šebela, S., Petro, L., Bella, P., Gaal, L. \& C. Ormukov, 2015: Evidence of a plate-wide tectonic pressure pulse provided by extensometric monitoring in the Balkan Mountains (Bulgaria).Geologica Carpathica, 66, 5, 427-438. DOI: https:// doi.org/10.1515/geoca-2015-0035. 
Cacoń, S., Košták, B. \& K. Mąkolski, 1993: Monitoring and interpretation of ground deformation of a cave.- In: Teskey, W.F. et al. (eds.) Proceedings of the Seventh International FIG Symposium on Deformation Measurements together with Sixth Canadian Symposium on Mining Surveying, $3^{\text {rd }}-5^{\text {th }}$ May, 1993, Banff, Canada. Dept. of Geomatics Engineering, University of Calgary, 440-449, Banff.

Camelbeeck, T., Ruymbeke, M., Quinif, Y., Vandycke, S., Kerchove, E. \& Z. Ping, 2012: Observation and interpretation of fault activity in the Rochefort Cave (Belgium).- Tectonophysics, 581, 48-61. DOI: https://doi.org/10.1016/j.tecto.2011.09.027.

Dabovski, C., Boyanov, I., Zagorchev, I., Nikolov, T., Sapounov, I., Khrischev, K. \& Y. Yanev, 2002: Structure and Alpine evolution of Bulgaria.- Geologica Balcanica, 32, 2-4, 9-15.

Dobrev, N. \& E. Avramova-Tacheva, 1997: Analysis and prognostication of monitored rock deformations.- In: Marinos, P.G. (ed.) Engineering geology and the environment: proceedings International Symposium on Engineering Geology and the Environment, organized by the Greek National Group of IAEG, $23^{\text {rd }}-27^{\text {th }}$ June 1997, Athens, Greece. Balkema, 613-618, Rotterdam.

Dobrev, N., 2010: In-Situ Monitoring of Cracks Affecting The Madara Horseman Historical Rock Monument, Northeastern Bulgaria.- In: Proceedings of the 1st International Applied Geological Congress, $26^{\text {th }}-28^{\text {th }}$ April, 2010, Mashhad, Iran. Islamic Azad University-Mashhad Branch, 2115-2120, Mashhad.

Eper-Pápai, I., Mentes, G., Kis, M. \& A. Koppán, 2014: Comparison of two extensometric stations in Hungary.- Journal of Geodynamics, 80, 3-11. DOI: https://doi.org/10.1016/j.jog.2014.02.007.

Frangov, G., Ivanov, P., Dobrev, N. \& I. Iliev, 1992: Stability problems of the rock monument "Madara Horseman".- In: Delgado Rodrigues, J. et al. (eds.) Proceedings of the 7th international congress on deterioration and conservation of stone, $15^{\text {th }}$ - $18^{\text {th }}$ June 1992, Lisbon, Portugal. Laboratório Nacional de Engenharia Civil, 1425-1435, Lisbon.

Gosar, A., Šebela, S., Košták, B. \& J. Stemberk, 2009: Surface versus underground measurements of active tectonic displacements detected with TM 71 extensometers in Western Slovenia.- Acta Carsologica, 38, 2-3, 213-226. DOI: https://doi.org/10.3986/ ac.v38i2-3.123.

Gosar, A., Šebela, S., Košták, B. \& J. Stemberk, 2011: On the state of the TM71 extensometer monitoring in Slovenia: Seven years of micro-tectonic displacement measurements.- Acta Geodyn. Geomater., 8, 4, 389-402.
Hadjiev, G., Katzkov, N. \& Tz. Tzankov, 1977: Lithological and structural investigations of the Madara Horseman.- Proc. "Museums and cultural monuments", VIII, 4, 20-35 (in Bulgarian).

Iliev, I., 1963: Physicomechanical properties of the rock upon which the Madara Horseman is carved.Priroda, 3, 65 (in Bulgarian).

Karagjuleva, J., 1971: Provadia Syncline (in Bulgarian).In: Bončev, E. (ed.) Tectonics of the Fore-Balkan. Publ. House of BAS, pp. 99-101, Sofia.

Klimchouk, A.B., Amelichev, G.N., Tymokhina, E.I. \& S.V. Tokarev, 2013: Hypogenic speleogenesis in the Crimean fore-mountains (the Black Sea region, South Ukraine) and its role in the regional geomorphology.- In: Filippi, M. \& P. Bosák (eds.) Proceedings of the 16th International Congress of Speleology, Volume 3, $21^{\text {st }}-28^{\text {th }}$ July 2013, Brno. Czech Speleological Society and the SPELEO2013 and in the cooperation with the International Union of Speleology, 364-365, Brno.

Klimeš, J., Rowberry, M.D., Blahůt, J., Briestenský, M., Hartvich, F., Košták, B., Rybář, J., Stemberk, J. \& P. Štěpančíková, 2012: The monitoring of slow-moving landslides and assessment of stabilisation measures using an optical-mechanical crack gauge.- Landslides, 9, 3, 407-415. DOI: https://doi.org/10.1007/ s10346-011-0306-4.

Kontny B., Cacoń, S., Košták, B. \& J. Stemberk, 2005: Methodic analysis of data obtained by monitoring microtectonic movements with TM-71 crack gauges in the Polish Sudeten.- Acta Geodyn. Geomater., 2, 3, 57-67.

Kostadinov, I., Shanov, S. \& J. Karagjuleva, 1992: Seismotectonic prognosticating and regionalizing of North-East Bulgaria.- Geologica Balcanica, 22, 1, 83-104 (in Russian).

Košták, B., 1991: Combined indicator using moiré technique.- In: Sørum, G. (ed.) Field Measurements in Geomechanics: Proceedings of the 3rd International Symposium on Field Measurements in Geomechanics, $9^{\text {th }}-11^{\text {th }}$ September 1991, Oslo. Balkema, 53-60, Rotterdam.

Košták, B., Cacoń, S., Dobrev, N.D., Avramova-Tacheva, E., Fecker, E., Kopecký, J., Petro, L., Schweizer, R. \& A.A. Nikonov, 2007: Observations of tectonic microdisplacements in Europe in relation to the Iran 1997 and Turkey 1999 earthquakes.- Izvestiya, Physics of the Solid Earth, 43, 6, 503-516. DOI: https://doi.org/10.1134/s1069351307060080.

Košták, B., Dobrev, N., Zika, P. \& P. Ivanov, 1998: Joint monitoring on a rock face bearing an historical basrelief.- Quarterly Journal of Engineering Geology and Hydrogeology, 31, 1, 37-45. DOI: https://doi. org/10.1144/gsl.qjeg.1998.031.p1.04. 
Kostov, K., 2014: The Immediate Earthquake impact on Caves: Eyewitness Data.- Buletini i Shkencave Gjeologjike - Special Issue. Proceedings of XX Congress of CBGA, 383-386.

Kostov, K. \& V. Nikolov, 2013: Karst in Neogene Limestones along the Northern Bulgarian Black Sea Coast.- In: Abstracts Book, 5th International Workshop on the Neogene from the Central and SouthEastern Europe, $16^{\text {th }}-20^{\text {th }}$ May 2013, Varna. Geological Institute BAS, 28-29, Sofia.

Mąkolski, K., Cacoń, S., Jamroz, O., Košták, B. \& M. Kaczałek, 2008: Investigations regarding Bear Cave massif (Lower Silesia) long-term stability.- Acta Carsologica, 37, 2-3, 279-290. DOI: https://doi. org/10.3986/ac.v37i2-3.152.

Matova, M., Dobrev, N. \& B. Košták, 2001: Certain extensometric data for the influence of the 1999-2000 Turkish earthquakes to Bulgaria.- In: Fourth Turkish-German Joint Geodetic Days, vol. II, April 2001, Berlin. 769-776, Berlin.

Mircheva, M., Iliev, Z. \& K. Kostov, 2004: The caves on the Madara Plateau.- Iskar, pp. 42, Sofia (in Bulgarian with English summary).

Načev, I. \& L. Slavova-Načeva, 1961: Lithology of the Upper Cretaceous Rocks in the North-Eastern Bulgaria.- Works on the Geology of Bulgaria. Series Stratigraphy \& Tectonics, 3, 171-233 (in Bulgarian).

Nikolov, T., 1969: Stratigraphy of the Lower Cretaceous in a part of North-Eastern Bulgaria.- Bull. of the Geological Institute, Series Stratigraphy and Lithology, 18, 31-71 (in Bulgarian).

Radu, C., Rădulescu, D. \& H. Sandi, 1990: Some data and considerations on recent strong earthquakes of Romania.- Cahier Technique, 3, 19-31.

Rowberry, M.D., Kriegner, D., Holy, V., Olejnik, K., Llull, M., Frontera, C. \& X. Marti, 2016: The instrumental resolution of a moiré extensometer in light of its recent automatization.- Measurements, 91, 258-265. DOI: doi.org/10.1016/j.measurement.2016.05.048.

Šebela, S., Gosar, A., Košták, B. \& J. Stemberk, 2005: Active tectonic structures in the W part of Slovenia Setting of micro-deformation monitoring net.- Acta Geodyn. Geomat., 2, 1, 45-57.

Šebela, S., Košták, B. \& J. Stemberk, 2010: Recent microtectonic movement from three karst caves, Slovenia.- In: Christofides, G. et al. (eds.) Proceedings of XIX Congress of CBGA, 23 $3^{\text {rd }}-26^{\text {th }}$ September 2010, Thessaloniki. Aristotle University of Thessaloniki, 513-518, Thessaloniki.

Šebela, S., Turk, J., Mulec, J., Košták, B. \& J. Stemberk, 2009: Statistical evaluation of the 3D monitoring of displacements of Dinaric Fault Zone in Postojna Cave, Slovenia.- Acta Geodyn. Geomater., 6, 2, 163-176.
Shanov, S. \& K. Kostov, 2015: Dynamic Tectonics and Karst.- Springer Verlag Berlin-Heidelberg, pp. 123, Berlin. DOI: https://doi.org/10.1007/978-3-66243992-0.

Shebalin, N.V., Karnik V. \& D. Hadzievski, 1974: Catalogue of earthquakes. UNDP/UNESCO Survey of the seismicity of the Balkan region.- UNESCO, pp. 600, Skopje.

Solakov, D. \& S. Simeonova, 1993: Bulgaria Catalogue of earthquakes 1981-1990. Bulgarian Academy of Sciences, Geophysical Institute, Seismological department, pp. 38, Sofia.

Stemberk, J., Briestenský, M. \& N. Jurková, 2008: Displacements registered in the selected caves of the Bohemian Massif.- Speleoforum 2008, 27, 141-144.

Stemberk, J., Hartvich, F., Blahut, J. \& O. Krejčí, 2017: Tectonic strain changes affecting the development of deep seated gravitational slope deformations in the Bohemian Massif and Outer Western Carpathians.- Geomorphology, 289, 3-17. DOI: https://doi. org/10.1016/j.geomorph.2016.07.004.

Toula, F., 1890: Geologische Untersuchungen in Östlichen Balkan.- In: Denkschriften der Kaiserlichen Akademie der Wissenschaften, MathematischNaturwissenschaftliche Classe. Aus der KaiserlichKöniglichen Hof- und Staatsdruckerei, 323-400, Wien.

Tzankov, V., 1943: Le plateau de Provadia, et le dôme de sel du nord-est étude géologique.- Rev. Bulg. Geol. Soc., Vol. XIV, 2, 83-123 (in Bulgarian with French abstract).

Vaptzarov, I. \& K. Mishev, 1982: Main features and dynamics of morphostructures in Bulgaria: significance of seismic zoning.- Geologica Balcanica, 12, $1,99-114$.

Varnes, D.J., 1978: Slope movement types and processes.In: Schuster, R.L. \& R.J. Krizek (eds.) Landslides, analysis and control. Special Report 176. Transportation Research Board, 11-33, Washington.

Venkov, V. \& N. Kossev, 1974: Studying on the rocks in the range of the Madara Horseman monument envisaging its conservation.- Proc. "Investigation and conservation of the cultural monuments in Bulgaria”, 83-97 (in Bulgarian).

Yolkichev, N., 1988: Lithostratigraphic units related to the Upper Cretaceous Series in the eastern part of Moesian Plate.- Rev. Bulg. Geol. Soc., Vol. 49, 1, 11 26 (in Bulgarian with English abstract). 